\title{
Analisa Manajemen Strategi Sistem Informasi Dalam Meningkatkan Pelayanan Menggunakan Metode SWOT (Studi Kasus PT XYZ)
}

\author{
Endang Supriyadi ${ }^{1}$, Maya Sofiana ${ }^{2}$
}

\begin{abstract}
Aviation industry is one of the industries in the field of transportation that today the number of user growth is increasing rapidly. In this paper described in general the aspects that effect the strategic decisions of airlines in the framework of implementation of the vision-mission of the organization, especially by PT XYZ, one of the state-owned airlines (SOEs) that has the scale and scope of business as well as the quality of service and international safety. Analysts will be focused on the business components of the company as well as strategies designed and implemented by the company in terms of achieving competitive advantage as well as risk management from various levels of volatile components such as the price of fuel oil (avtur, etc.). The writing method used is the research methodology used in this study using descriptive research methodology or literature review. Data analysis using SWOT analysis method. The results showed that there were company committed to implementing the right producing strategy for PT XYZ. to improve services.
\end{abstract}

Intisari- Salah satu bidang transpotasi yang berkembang dengan pesat adalah industri penerbangan, Dalam tulisan ini diuraikan faktor-faktor umum yang berdampak pada keputusan strategis dalam rangka penerapan misi-visi perusahaan khususnya oleh PT XYZ, salah satu dari perusahaan maskapai penerbangan yang skala usaha dan ruang lingkup serta kualitas pelayanan dan keamanan internasional. Analisa akan fokus pada aspek-aspek bisnis organisasi serta penyusunan strategi yang dibangun dan diimplementasikan oleh organisasi dalam rangka meraih keunggulan kompetitif serta manajemen risiko dari berbagai level komponen volatil seperti tingkat harga avtur diantaranya. Dalam penelitian ini metode yang digunakan metodologi penelitian deskriptif dengan pendekatan studi pustaka. Analisa data menggunakan metode analisis SWOT. Hasil penelitian menunjukkan bahwa ada komitmen perusahaan untuk menerapkan strategi produksi yang tepat bagi PT XYZ untuk meningkatkan layanan.

Kata Kunci-Strategi Sistem Informasi, Pelayanan, SWOT.

\footnotetext{
1,2 Program Vokasi (D3), Institut Ilmu Sosial dan Manajemen STIAMI, Jl. Tipar Cakung No. 81A, Jakarta Timur (tlp: 02122476600; e-mail: endangs2013@gmail.com, mayasofiana72@gmail.com)
}

\section{Pendahuluan}

Proses pengambilan keputusan manajemen mengalami perkembangan karena adanya kompleksitas dan tuntutan perkembangan organisasi untuk responsif dan adaptif terhadap lingkungan organisasi. Hal ini tidak terlepas dari aspek yang penting dan berharga dalam organisasi yakni informasi, seperti kita ketahui keakuratan dan kecepatan informasi sangat mendukung pertumbuhan dan perkembangan organisasi. Oleh karena itu, sangatlah penting pengelolaan informasi untuk menunjang kelancaran pekerjaan dan untuk menganalisis histori dari pekerjaan tersebut. Terkait dengan hal tersebut, sangat penting untuk menguasai Sistem Informasi Manajemen yang meliputi penciptaan, pendistribusian, dan pemanfaatan informasi untuk mendukung kegiatan manajemen secara umum dan pada pembuatan keputusan dalam kebijakan public secara khusus.

Akan tetapi fenomena yang terjadi banyak organisasi yang yang mengalami kegagalan padahal telah berencana membangun Sistem Informasi Manajemen untuk keperluan sendiri, dan menyiapkan dana yang cukup besar. Hal ini disebabkan karena diantaranya struktur organisasi yang tidak mendukung, rencana organisasi yang tidak matang, sumber daya manusia yang tidak kompeten serta kurangmya dukungan dari manajemen seperti partisipasi pihak manajemen dalam perancangan system, pengendalian upaya pengembang system serta memotivasi pihak-pihak yang terlibat.

Untuk membahas Sistem Informasi Manajemen (SIM/) lebih lanjut, sebelumnya perlu dipahami definisi dari SIM yaitu: "rangkaian sub-sistem informasi yang secara menyeluruh, berinteraksi dan secara logika memiliki kemampuan untuk merubah data hingga menjadi informasi dengan berbagai ragam bentuk dan guna meningkatkan kinerja berdasarkan gaya dan sifat manajer" [1]

\section{TINJAUAN PUSTAKA}

\subsection{Manajemen Strategi}

Mulyadi berpendapat bahwa Manajemen Strategi [2], adalah rangkaian proses yang dilaksanakan oleh pihak manajer dan karyawan dalam hal perumusan dan pelaksanaan bentuk strategi dalam mendukung penyediaan customer value terbaik dalam rangka mewujudkan misi dan visi organisasi. Sementara itu Hariadi memaparkan [3] definisi manajemen strategi merupakan proses penyusunan secara sistematis oleh 
manajemen terkait strategi, pengimplementasikan strategi, dan evaluasi terhadap jalannya strategi tersebut. Rangkaian kegiatan tersebut di atas dilakukan bertujuan untuk merealisasikan visi-misi organisasi.

\subsection{Sistem Informasi Manajemen}

Definisi Sistem Informasi Manajemen [4] adalah suatu sistem berbasis komputer yang mendukung tersedianya data dan informasi bagi para pengguna yang memiliki kebutuhan yang sejenis. Informasi menjelaskan histori pekerjaan atau proses bisnis atau diantara satu sistem utamanya mengenai di masa lalu apa yang telah terjadi, saat ini apa yang tengah terjadi dan apa yang mungkin dapat terjadi di waktu yang akan datang. Sementara itu menurut pendapat Hartono [5] pengertian SIM adalah sekumpulan interaksi sistem-sistem informasi yang bertanggung jawab dalam pengolahan dan pengumpulan data untuk mendukung informasi yang penting untuk semua tingkatan manajemen dalam rangka aktivitas perencanaan dan pengendalian

\subsection{Pelayanan}

Kotler berpendapat bahwa [6] pelayanan adalah semua aktivitas atau penawaran kegiatan oleh pihak satu kepada pihak yang lain, yang intangible dan tidak menjadi sebab kepemilikan apapun. Hal ini sependapat dengan [7] pelayanan adalah rangkaian aktivitas secara terus menerus dan berkelanjutan yang mencakup keseluruhan eksistensi personal dalam kehidupan masyarakat. Selanjutnya Moenir[8] menyatakan bahwa pelayanan merupakan kegiatan-kegiatan yang menguntungkan baik dalam bentuk kumpulan atau kesatuan, juga menawarkan kepuasan walaupun hasilnya tidak selalu berbentuk produk fisik. Hal ini menggambarkan bahwa pelayanan berhubungan dengan kepuasan batin penerima pelayanan. Sedangkan Lijan mendefinisikan pelayanan [9] adalah suatu rangkaian kegiatan yang bersifat intangible yang timbul karena sebagai akibat adanya keterhubungan antara penerima jasa dengan penyedia jasa atau hal-hal lain yang disediakan oleh perusahaan penyedia pelayanan untuk memberikan solusi atas permasalahan konsumen.

\subsection{Pengertian Analisis SWOT}

Analisis SWOT merupakan metode perencanaan strategis untuk alat evaluasi kekuatan (strengths), kelemahan (weaknesses), peluang (opportunities), dan ancaman (threats) pada suatu aktivitas proyek atau suatu spekulasi bidang bisnis. Faktor-faktor itulah yang diakronimkan sebagai SWOT (strengths, weaknesses, opportunities, dan threats).

\section{METODE PENELITIAN}

Dalam penelitian ini menggunakan metodologi penelitian deskriptif berbasis kajian pustaka. Kegiatan pengumpulan data dilakukan dengan menggunakan kuesioner dan studi dokumen mencakup pembahasan teoritis yang berkaitan dengan masalah-masalah penelitian.
Menurut pendapat Sujarweni [10] bahwa kajian pustaka memiliki fungsi membangun konsep atau teori yang menjadi landasan bagi studi didalam sebuah penelitian. Untuk mengembangkan aspek teoritis dan praktis pada penelitian akademik maka penelitian studi pustaka wajib dilakukan hal tersebut sesuai dengan pendapat Sukardi (2013:33) bahwa kajian pustaka atau studi pustaka adalah aktifitas yang diwajibkan pada penelitian, khususnya penelitian akademik yang utamanya bertujuan mengembangkan aspek teoritis maupun aspek manfaat praktis. Berikut ini merupakan tahapantahapan penelitian yang telah dilakukan yaitu

\subsection{Pengolahan Data}

Pengolahan data dalam penelitian ini merujuk berdasarkan konsep Miles \& Huberman, yaitu :

1. Pengumpulan data menggunakan metode kualitatif dapat dilakukan sebelum atau saat bahkan sesudah penelitian.

2. Reduksi data; dilakukan dengan cara menggabungkan dan menyeragamkan berbagai macam bentuk data yang telah diperoleh sehingga menjadi bentuk lain seperti bentuk script yang kemudian dilakukan Analisa. Sedangkan hasil observasi, hasil studi dokumen diubah menjadi tulisan sesuai dengan formatnya masing-masing.

3. Display data; merupakan kegiatan pengolahan data setengah jadi yang sudah seragam ke bentuk tulisan dan telah memiliki rangkaian alur tema yang jelas dalam suatu matriks kategorisasi sesuai tema-tema yang sudah dikelompokkan dan dikategorikan serta akan memecah tema-tema tersebut ke dalam bentuk yang lebih nyata dan sederhana yang disebut dengan subtema, diakhiri dengan memberikan kode dari subtema tersebut.

4. Kesimpulan; dalam analisa data kualitatif menurut model interaktif yang dipaparkan oleh Miles \& Huberman secara mendasar berisi tentang penjelasan secara detail dari seluruh subkategorisasi tema yang tercantum pada tabel kategorisasi dan pengkodean yang sudah diselesaikan.

\subsection{Diagram Alur Penelitian}




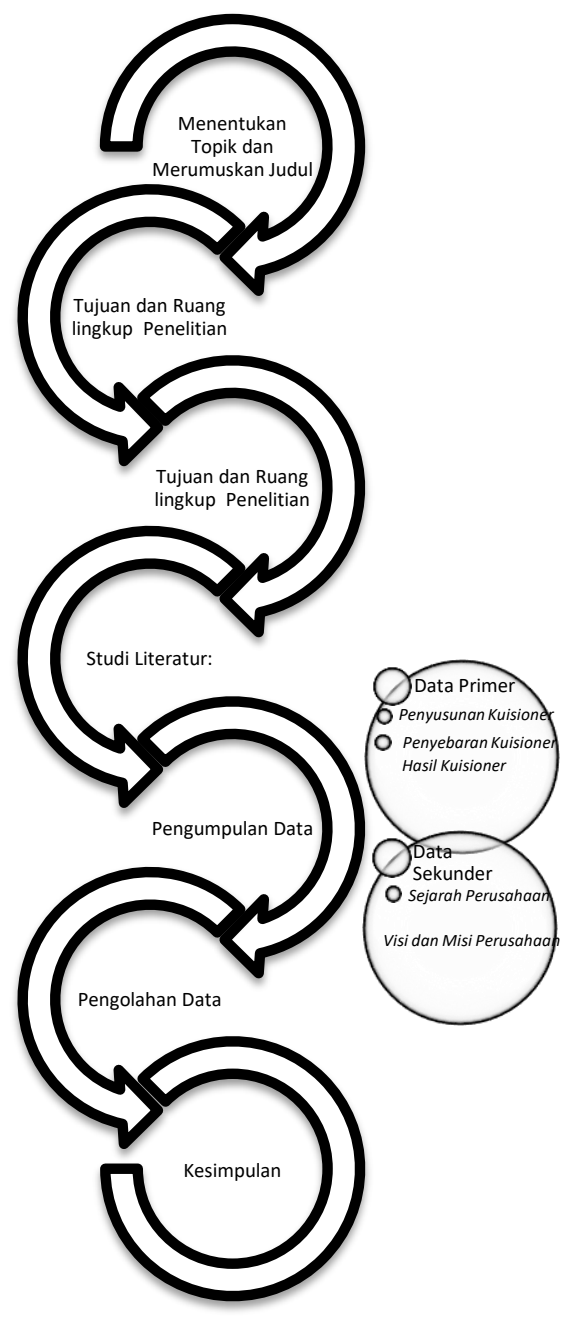

Gambar 1. Diagram Alir Penelitian

\section{HASIL DAN PEMBAHASAN}

\subsection{Analisis Strategi SWOT}

Adapun hasil penelitian ini didapat dari kajian pustaka dari beberapa hasil penelitian beberapa peneliti yakni pada bagian ini Analisis SWOT digunakan untuk menginetifikasi dan menganalisis faktor-faktor strategis internal dalam kerangka Strenght dan Weaknesses serta faktor-faktor strategis eksternal dalam rangka Opportunity dan Threat. Serta untuk menentukan alternatif strategi dan penentuan pilihan strategi pengembangan PT XYZ.

\section{Strenght (Kekuatan)}

a) Maskapai penerbangan PT XYZ memiliki 143 pesawat yang terdiri dari 9 pesawat jenis Boeng 777-300ER, 2 pesawat jenis Boeing 747-400, 13 pesawat jenis Airbus 330-300, 9 jenis pesawat Airbus A330-200, 81 pesawat
Boeng 737-800NG, 18 pesawat CRJ1000 NexGen (pesawat perintis), dan 11 pesawat jenis ATR 72-600 (pesawat perintis).

b) PT XYZ hingga tahun 2016 memiliki 40 rute penerbangan domestik dan 36 rute internasional.

Perusahaan ini selalu menempatkan pelanggan sebagai perhatian utama dengan berlandaskan keramahtamahan dan keunikan Indonesia yang disebut dengan " $P T X Y Z$ Indonesia Experience" yang didasarkan pada 5 sense yaitu sight, sound, smell, taste, and touch, menjadikan PT XYZ mempunyai ciri khas tersendiri dibandingkan dengan maskapai penerbangan lain.

c) Adanya layanan "Immigration on Board" yang merupakan inovasi PT XYZ dan merupakan satusatunya maskapai penerbangan di dunia, yaitu layanan pemberian visa di atas pesawat.

d) Memiliki tim yang terdiri dari sumber daya manusia yang handal, professional, kompeten, berdaya saing tinggi dan helpful serta dilandasi atas nilai-nilai FLY-HI (effecien \& effective, Loyalty, customer centricity, Honesty \& openness, and Integrity) di setiap insan PT XYZ. Hal tersebut dibuktikan dengan perolehan penghargaan "World's Best Cabin Crew" sejak tahun 2016 dari Skytrax (London, UK).

e) PT XYZ menjadi maskapai paling diminati untuk penerbangan internasional, dengan pasar $16,54 \%$ atau sebanyak 4,17 juta penumpang dari total penumpang internasional sepanjang 2015.

f) Memiliki teknologi informasi yang mutakhir dalam menjalankan bisnis sehingga menepatkan PT XYZ sebagai maskapai penerbangan dengan TI tercanggih di Indonesia.

g) PT XYZ banyak melakukan kegiatan CSR seperti program kemitraan dan bina lingkungan sebagai bentuk kepedulian dan tanggung jawab kepada masyarakat.

h) PT XYZ termasuk dalam kategori baik untuk hal tata kelola perusahaan (Good Corporate Governance)

i) PT XYZ telah memiliki brand yang kuat dan telah diakui di pasar domestik dan internasional (kualitas pelayanan dan keselamatan dengan standar 5-star airline).

2. Weaknesses (Kelemahan)

a) PT XYZ memiliki keterbatasan jumlah cockpit dan cabin crew sehingga menyebabkan keterlambatan penerbangan.

b) PT XYZ memiliki tingkat hutang yang tinggi terutama sekali pada akun-akun lancar yang diakibatkan adanya peningkatan dalam jumlah kewajiban pada akun-akun lancar seperti hutang usaha dan biaya yang masih harus dibayar.

c) Belum dapat melakukan pembagian dividen kepada para pemegang saham

d) Otomatisasi sistem sangat diandalkan sehingga apabila terjadi kesalahan sistem akan mengganggu kegiatan proses bisnis perusahaan. 
e) Karena perusahaan mengedepankan konsep pelayanan full service maka mengakibatkan harga tiket pesawat menjadi lebih tinggi dibandingkan maskapai penerbangan lainnya.

\section{Opportunities (Peluang)}

a) Negara Indonesia merupakan salah satu negara yang memiliki pangsa pasar penerbangan yang sangat pesat dibandingkan dengan negara lainnya terlihat dengan meningkatnya pertumbuhan pesawat terbang dari tahun ke tahun. Jika dibandingkan dengan Negara lain kegiatan lalu lintas udara di Negara Indonesia masih terlalu kecil dibandingkan dengan populasi penduduk Indonesia yang menggunakan jasa pesawat terbang yaitu hanya $42 \%$ dari total penduduk sebesar 249,9 juta)

b) PT XYZ telah lama bergabung dengan anggota aliansi global maskapai penerbangan benama SkyTeam Global Airline Alliance yang menjadi presensi baik bagi perusahaan dalam rangka peningkatan jangkauan dan akses terbang terhadap bebagai destinasi lintas Negara dalam memperluas cakupan pasar internasional.

c) Meningkatnya proyek pengembangan dan pembangunan bandara utama dan baru di Indonesia dengan total estimasi anggaran proyek mencapai USD 4,2 Milyar ( tahun 2014- 7 bandara, tahun 2015- 5 bandara, tahun 2016- 2 bandara, tahun 2017-2018 - 4 bandara) yang implementasinya tersebar merata diseluruh tanah air.

\section{Threat (Ancaman)}

a) Keterbatasan fasilitas bandara adalah salah satu factor yang menghambat ketepatan waktu penerbangan diantaranya adalah keterbatasan landasan pacu / run way.

b) PT XYZ hanya mengandalkan pasokan bahan bakar dari Pertamina saja yang merupakan sumber bahan bakar utama.

c) Semakin banyaknya rute penerbangan baru yang telah dibuka oleh maskapai penerbangan lainnya sehingga mengakibatkan penurunan harga tiket.

d) Maskapai asing melakukan penetrasi pasar ke Indonesia.

e) Bencana Alam dan faktor-faktor yang tidak terhindarkan lainnya.

\section{Matriks SWOT}

Berikut ini gambaran strategi yang dapat digunakan oleh PT XYZ untuk dapat meningkatkan pelayanannya yang tergambar dalam bentuk matrik analisis SWOT.
Table 1. Matrik Analisis SWOT

\begin{tabular}{|c|c|c|}
\hline EKSTERNAL & $\begin{array}{l}\text { STRENGHS } \\
\text { 1. PT XYZ merupakan } \\
\text { maskapai penerbangan } \\
\text { terbesar di Indonesia. } \\
\text { 2. Meningkatkan pelayanan } \\
\text { 3. Memiliki brand maskapai } \\
\text { internasional yang sangat } \\
\text { kuat. } \\
\text { 4. Memiliki rute } \\
\text { penerbangan yang } \\
\text { banyak. } \\
\text { 5. Memiliki teknologi } \\
\text { informasi yang modern } \\
\text { dan terkini. }\end{array}$ & $\begin{array}{l}\text { WEAKNESSES } \\
\text { 1. Sering bermasalah } \\
\text { pada sistem online. } \\
\text { 2. Memiliki range harga } \\
\text { penerbangan di atas } \\
\text { rata-rata. } \\
\text { 3. Pembagian dividen } \\
\text { kepada para } \\
\text { pemegang saham. } \\
\text { tidak dapat dilakukan. } \\
\text { 4. Memiliki tingkat } \\
\text { hutang lancar } \\
\text { perusahaan yang } \\
\text { sangat tinggi. } \\
\text { 5. Biaya operasional } \\
\text { yang sangat tinggi. }\end{array}$ \\
\hline $\begin{array}{l}\text { OPPORTUNITIES } \\
\text { 1. BUMN sebagai } \\
\text { tempat bernaung. } \\
\text { 2. Teknologi } \\
\text { internet. } \\
\text { 3. Persaingan antar } \\
\text { maskapai low- } \\
\text { cost. } \\
\text { 4. Demand jasa } \\
\text { penerbangan }\end{array}$ & 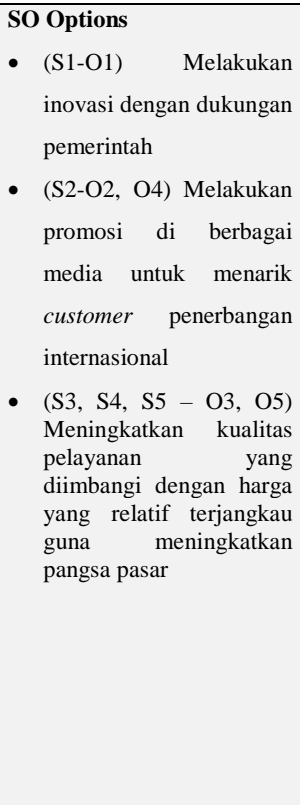 & 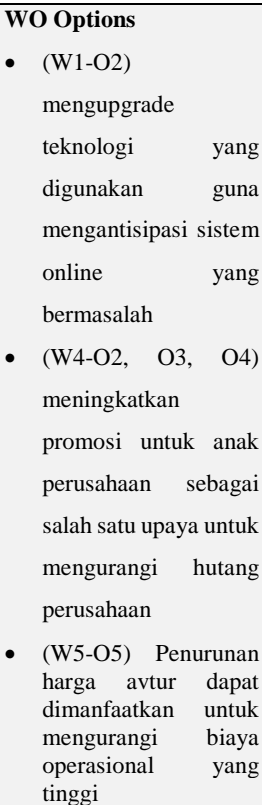 \\
\hline $\begin{array}{l}\text { THREATS } \\
\text { 1. Keadaan alam } \\
\text { sulit diprediksi } \\
\text { 2. Malfungsi } \\
\text { jaringan sistem } \\
\text { online } \\
\text { 3. Biaya } \\
\text { maintenance, } \\
\text { repair and } \\
\text { overhaul (MRO) } \\
\text { di Indonesia } \\
\text { yang mahal } \\
\text { 4. Pelemahan nilai } \\
\text { mata uang rupiah } \\
\text { 5. Persaingan } \\
\text { dalam hal } \\
\text { periklanan }\end{array}$ & $\begin{array}{l}\text { ST Option } \\
\text { - }(\mathrm{S} 2, \quad \mathrm{~S} 4, \quad \text { S5-T5) } \\
\text { menggunakan brand } \\
\text { yang kuat untuk menarik } \\
\text { konsumen khususnya } \\
\text { melalu periklanan } \\
\text { - }(\mathrm{S} 1-\mathrm{T} 3, \mathrm{~T} 4) \\
\text { memaksimalkan strategi } \\
\text { untuk mengatasi kondisi } \\
\text { nilai mata uang rupiah } \\
\text { yang melemah serta } \\
\text { efisiensi } \\
\text { pengeluaran biaya }\end{array}$ & 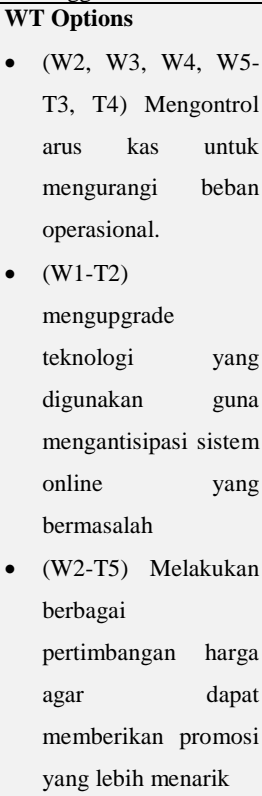 \\
\hline
\end{tabular}




\section{KESIMPULAN DAN SARAN}

\subsection{Kesimpulan}

Pertumbuhan industri penerbangan saat ini sangat pesat berbanding lurus dengan persaingan maskapai penerbangan yang semakin kuat. Perusahaan maskapai penerbangan akan mampu bertahan apabila memiliki strategi perusahaan yang baik. Beberapa langkah dalam perencanaan strategi yang tepat yakni tahap input yaitu tahap pencocokan, dan tahap keputusan. Tahap input terdiri dari matriks IFAS yang membahas kekuatan dan kelemahan internal perusahaan maskapai penerbangan, sedangkan matriks EFAS membahas faktor eksternal perusahaan berkaitan dengan peluang dan ancaman. Selanjutnya pada tahap SWOT ( strategi S-O ) yaitu menggunakan kekuatan perusahaan untuk memanfaatkan peluang yang ada, sedangkan (Strategi W-O ) bertujuan untuk mengurangi kelemahan dengan memanfaatkan peluang yang ada, (Strategi S-T) bertujuan menggunakan kekuatan untuk menghindari ancaman, (Strategi W-T) bertujuan untuk mengurangi kelemahan dan menolak ancaman.

Tahap akhir dari penelitian ini menghasilkan bahwa strategi yang tepat dapat digunakan oleh PT XYZ bertujuan untuk meningkatkan kepuasan pelayanan adalah sebagai berikut :

1 Strategi integrasi yakni strategi kedepan dengan mencari kepemilikan atau meningkatkan kontrol atas distributor maupun pengecer yang bertujuan agar lebih mendekat kepada end user. Contoh implementasi dari strategi ini yaitu dengan mengembangkan anak perusahaan di bidang travel yang sepenuhnya menggunakan fasilitas PT XYZ.

2 Strategi intensif yakni penetrasi pasar dengan meningkatkan pangsa pasar untuk produk/jasa saat ini dipasar melalui upaya pemasaran yang lebih besar. Contoh implementasinya yaitu meningkatkan jumlah tenaga penjual sebagai respon terhadap produk layanan baru yang dikembangkan.

3 Strategi diversifikasi yakni concentric dengan menambah produk/jasa bary uang masih berkaitan dengan produk/jasa lama. Sebagai contoh bidang pelayanan yanglebih spesifik seperti telah dilakukan sebelumnya yakni first class, serta terus mengembangkan rute-rute penerbangan baru.

4 Strategi definsi yakni retrenchment, apabila terjadi kemunduran terus menerus perlu dilakukan pengelompokan ulang melalui pengurangan aset dan biaya untuk membalikkan penjualan dan laba yang menurun.

5 Strategi kerja sama yakni joint venture, apabila ingin melakukan kerja sama yang tepat adalah dengan membentuk kemitraan sementara dengan tujuan memanfaatkan peulang, dan

6 Strategi SWOT poin terbesar secara umum yaitu pada strategi S-T dengan mengoptimalkan strategi Quick Wins guna mengatasi kondisi nilai mata uang rupiah yang melemah serta efisiensi biaya pengeluaran. Strategi ini sudah diimplementasikan PT XYZ akan tetapi perlu mengontrol agar tujuan utama dapat tercapai.

\subsection{Saran}

Saran dari hasil penelitian ini yaitu :

1 Berdasarkan hasil yang ditemukan dapat diberikan saran bahwa secara keseluruhan atau simultan kualitas pelayanan yang berupa bukti fisik, keandalan, ketanggapan, jaminan dan empati berpengaruh terhadap kepuasan konsumen PT XYZ.

2 Diharapkan PT XYZ tetap menjaga kualitas hubungan dengan para konsumennya dan bahkan lebih meningkatkan lagi kualitas pelayanan secara menyeluruh.

3 Konsumen menginginkan PT XYZ meningkatkan pelayanan sebagaimana yang dijanjikan dengana kurat dan terpercaya, seperti pelayanan yang baik mengenai pelayanan Call Center, Sales Service, dan Ticketing Service.

4 Jadwal keberangkatan dan kedatangan yang tepat waktu sesuai dengan kecepatan dan kecekatan awak kabin dalam melayani kebutuhan penumpang selama penerbangan.

\section{REFERENSI}

[1] Ismail, Manajemen Perbankan, Jakarta: Prenadamedia, 2013.

[2] Mulyadi, Balance Scorecard : Alat Manajemen Kontemporer Untuk Pelipatganda Kinerja Keuangan Perusahaan, Jakarta: Salemba Empat, 2001.

[3] B. Hariadi, Strategi Manajemen, Jakarta: Bayumedia Publishing, 2003.

[4] R. M. Jr, Sistem Infoemasi Manajemen, Jakarta: Salemba Empat, 2012.

[5] J. Hartono, Pengenalan Komputer : Dasar Ilmu Komputer, Pemograman, Sistem Informasi dan Intelegensi Buatan, Yogyakarta: Andi, 2000

[6] Kotler, Prinsip-prinsip Pemasaran, Jilid I, Jakarta: Erlangga, 2008.

[7] Moenir, Manajemen Pelayanan Umum di Indonesia, Jakarta: PT Bumi Aksara, 2008.

[8] P. S. Lijan, Reformasi Pelayanan Publik, Jakarta: BumiAksara, 2008.

[9] Mahmoedin, Etika Pelayanan Bank, Jakarta: PT Gunung Agung, 2010 .

[10] Z. W. \&. M. Widiyanti, "Pengaruh Kualitas Pelayanan Terhadap Kepuasan Konsumen Jasa Penerbangan PT Garuda Indonesia Airline (Studi kasus konsumen di Kota Palembang)," JEMBATANJurnal Ilmiah Manajemen Bisnis dan Terapan, pp. 59-72, 2014. 


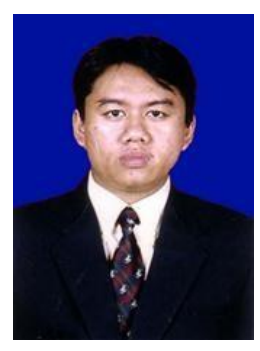

Endang Supriyadi, lahir di Jakarta, 14 Nopember 1974. Memperoleh gelar Diploma III (D3), Jurusan Manajemen Informatika Universitas Gunadarma Depok, lulus tahun 1998 dan memperoleh gelar Sarjana Al-Quran (SQ) dan gelar Sarjana Agama (S.Ag) Fakultas Tarbiyah Jurusan Pendidikan Agama Islam di Institut Perguruan Tinggi Ilmu Al-qur'an Jakarta ( IPTIQ ) lulus tahun 1999. Memperoleh gelar Magister Komputer (M.Kom) Program Pasca Sarjana Magister Ilmu Komputer Konsentrasi EBusiness STMIK Nusa Mandiri Jakarta, lulus tahun 2015. Pernah mengajar di STMIK Nusa Mandiri Jakarta, STIMA IMMI, STMIK Triguna Utama dan saat ini aktif mengajar di beberapa perguruan tinggi swasta lainnya : Politeknik LP3I Jakarta Kampus Depok, Institut Ilmu Sosial dan Manajemen STIAMI, Insititut Bisnis dan Ilmu Komputer ( IBIK57 ) Kosgoro serta menjadi anggota tim asesor LSP Politeknik LP3I Jakarta untuk kompetensi bidang ilmu komputer. Pendiri lembaga kursus computer LKP-PROTECH Depok :WWW.LKPPROTECH.COM dan pendiri cadasrtrwnet wilayah pancoranmas Depok. Selain itu aktif pula menulis buku panduan komputer aplikasi perkantoran dan artikel ilmiah yang pernah di publish dintaranya : Metode SVM Berbasis PSO untuk Meningkatkan Prediksi Ketepatan Waktu Kelulusan Mahasiswa, Analisa Web untuk Memahami Perilaku Konsumen Online Studi Kasus "Store Steam Powered" dll.

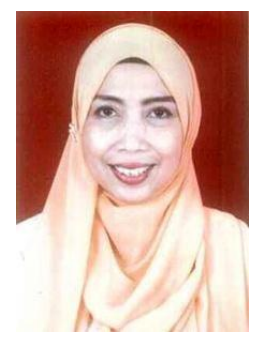

Maya Sofiana. Surabaya, 13 Mei 1972. Memulai pendidikan di Sekolah Menengah Atas Negeri (SMAN) 52, Jakarta lulus tahun 1991. Kemudian melanjutkan ke Ikip Jakarta d/h Universitas Negeri Fatultas Ilmu sosialProgram Studi Administrasi Perkantoran Jakarta tahun 1992 dan lulus tahun 1997. Lalu tahun 1998 melanjutkan Strata Dua (S2) Magister Manajemen di Universitas Jayabaya Jakarta lulus tahun 2000. Pernah bekerja di PT Aditya Apprasial Bhakti tahun 2000. Kemudian Tahun 2003. bekerja di Yayasan Widya Bhakti. Saat ini mengajar di beberapa kampus swasta Institut Ilmu Sosial dan Manajemen Stiami, Poltek LP3I Jakarta dan memberikan pelatihan Perkantoran karyawan di beberapa instansi Kemendikbud, dan Kementerian Pertahanan RI. Paper jurnal yang pernah dipublikasikana adalah sebagai berikut: Pelaksanaan Manajemen K3 pada PT Adyawinsa T 7 E di Jakarta (Majalah IlmiahBijak), Pelatihan Pengenalan Aplikasi Perkantoran ( Typing Master dan Word) bagi Remaja Karang Taruna RT 4 Kelurahan Cinere Kecamatan Cinere Depok Jawa Barat (Jurnal Komunitas-Jurnal Pengabdian Kepada Masyarakat), Prosedur Production Control pada PT Astra Honda Motor Jakarta (Jurnal Abiwara-Jurnal Vokasi Administrasi Bisnis), Studi Komparasi Kepuasan Pasien BPJS dan Non BPJS pada Mutu Pelayanan Pendaftaran Puskesma Johar Baru Jakarta Pusat (Jurnal Abiwara-Jurnal Vokasi Administrasi Bisnis), Green Office Concept Assesment in The Council Show The Office Care (Majalah Ilmiah Bijak). 